\title{
Human Resource Management Strategies: A Panacea for Quality Education Delivery
}

\author{
Briggs, Francis \\ Federal Government College, Port Harcourt, Nigeria. \\ Desmond, Elizabeth \\ Shalom Group of Schools, Port Harcourt, Nigeria.
}

\section{Doi:10.5901/mjss.2013.v4n16p43}

\begin{abstract}
Managing human resources in public secondary schools is of great important in the attainment of quality education delivery. The quality and quantity of human resources available will determine how the process-output will enhance continual growth in the educational system, since human resources organizes and coordinates other factors. This study examined human resource management strategies that enhances quality education delivery in public secondary schools in Rivers State.
\end{abstract}

\section{Introduction}

An organization exists for the purpose of creation of product(s) or providing services to clients or customers. The existence of any organization is centered on its workforce, which is the human resource. In a school system, human resource include the principal, vice principal, teachers, non academic staff and students. Human resources are the driving force in the school system, with the responsibility of making sure that goals and specific objectives are achieved in academics and extracurricular activities. Human resource management involves all management decisions and actions that affect the nature of the relationship between an organization and its employees. The decisions and actions according to Stoner, Freeman and Gilbert (1995) include; human resource planning, recruitment, selection, orientation, training and development, performance appraisal, and promotions, transfers, demotions and separations. Human resource management involves human resources needs, assisting in the design of work systems in terms of recruitment, selection, training development, counseling, motivation and rewarding employees, acting as liaison with unions and government organization and handling other matters of employees well -being.

For the activities of human resources management to be implemented effectively as to improve the quality of education, certain strategies are required of the human resource manager. These strategies according to Armstrong (2009) include: meeting the needs of employees for healthy, safe and supportive work environment, interpersonal relation between management and the employees, providing an environment in which employees are encouraged to learn and develop, attracting and retaining high quality people, continual reward for success, proper management of data, and planning and implementing of programmes designed to enhance the effectiveness with which organizations function and respond to change.

Quality education involves continual improvement in inputs, processes and outputs. These improvements are expected to includes: student enrolment, retention, gender ratio, student-teacher ratio, facilities, curriculum, assessment, training and development of students and teachers, improved result in external and internal examination, high moral standard, obedience to rules and regulations, etc. Improvement 
is expected to be total for quality to be achieved and that the school culture is required to be defined and supported by constant attainment of students, improvement through integrated strategies. If there is evaluation of quality work during supervision, use of competent staff, dissemination of information to teachers and students, teamwork, proper guidance and counseling and new research and development to invigorate all educational activities, then quality will continually improve in the educational system. Also, the implementation of these strategies in terms of the development of the teachers and students, improvement of the curriculum, delegation of responsibilities to staff and students, inclusion of staff and students in decision making and orientation will enhance quality education in public secondary schools in Rivers State.

\section{Statement of the Problem}

The problem is that, how can human resource be managed to improve quality education delivery. The study seek to find out how human resources are recruited, are those recruited exposed to training? And are compensation packages adequate?

\section{Purpose of the Study}

The purpose of the study was to:

1. Assess the method(s) adopted for the recruitment of human resources in public secondary schools in Rivers State.

2. Determine the training programmes attended by human resources.

3. Identify the compensation packages for human resources.

\section{Research Question}

1. What are the methods adopted to recruit human resources in public secondary schools in Rivers State?

2. What training programmes for staff will minimize indiscipline in public secondary schools in Rivers State?

3. What compensation packages for staff will improve their personal needs?

\section{Methodology}

The design of this research was the descriptive survey. The population was made up of 274 principals and three thousand eight hundred sixty-five (3865) teachers in the public secondary schools, making a total of four thousand, one hundred and thirty-nine (4139). These principals and teachers were considered as the most suitable to respond in the items of the questionnaire, which was used for the research. The sample involved 2500 respondents from the population. This represents $60.4 \%$ of the total population.

\section{Results}

Frequencies, percentages and bar charts are used to present the responses. Series1 represents strongly agree, series2 agree, series3 disagree and series4 strongly disagree in the bar charts

6.1 Research question 1: What are the methods adopted to recruit human resource in public secondary schools in Rivers State? 
Table 1: Frequency and percentage representation of the methods adopted to recruit human resource in public secondary schools.

\begin{tabular}{|c|l|c|c|c|c|c|c|c|c|}
\hline S/N & \multicolumn{1}{|c|}{} & \multicolumn{1}{|c|}{ SA } & $\%$ & A & $\%$ & D & $\%$ & SD & $\%$ \\
\hline 1 & $\begin{array}{l}\text { Adequate publicity is done to ensure that the most } \\
\text { qualified teachers are recruited }\end{array}$ & 107 & 5 & 577 & 24 & 1394 & 58 & 322 & 13 \\
\hline 2 & $\begin{array}{l}\text { Consultants are given the task of selection of reduce } \\
\text { the bureaucratic bottleneck }\end{array}$ & 314 & 13 & 518 & 22 & 1242 & 51 & 326 & 14 \\
\hline 3 & $\begin{array}{l}\text { Teachers recruitment is conducted when principal } \\
\text { make request in areas of needs }\end{array}$ & 419 & 17 & 630 & 26 & 1059 & 44 & 292 & 13 \\
\hline 4 & $\begin{array}{l}\text { Recruitment of teachers are always kept in view after } \\
\text { request from the principal for several years }\end{array}$ & 323 & 13 & 501 & 29 & 1147 & 48 & 429 & 18 \\
\hline 5 & $\begin{array}{l}\text { Recruitment is not necessarily based merit but equal } \\
\text { representation from all the local Government Area }\end{array}$ & 401 & 17 & 425 & 18 & 1265 & 52 & 309 & 13 \\
\hline
\end{tabular}

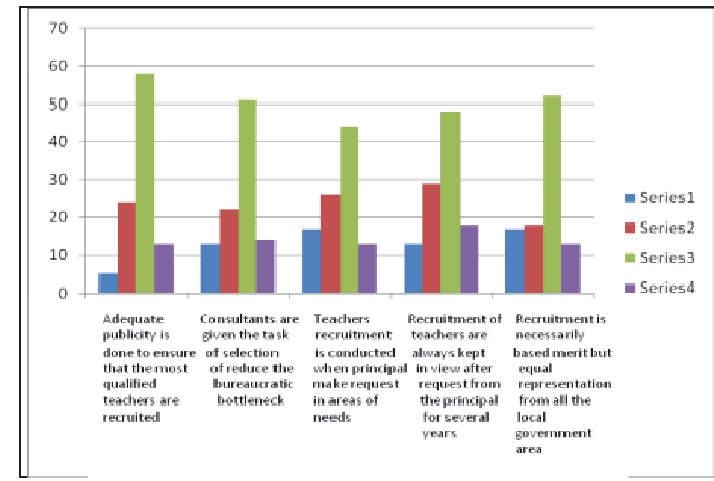

Figure 1: Frequency and percentage representation of the methods adopted to recruit human resource in public secondary schools.

Table 1 and figure 1 showed the frequency and percentage representation of respondents (principals and teachers) on the method adopted to recruit human resource in public secondary schools in Rivers State. Adequate publicity was not done to ensure that the most qualified teachers are recruited. Out of 2400 respondents, 107 (5\%) strongly agreed, 577 (24\%) agreed, 1394(58\%) disagreed and 322(13\%) strongly disagreed to the item. Consultants are given the task of selection to reduce the bureaucratic bottleneck, showed that 314(13\%) strongly agreed, 518(22\%) agreed, 1242(51\%) disagreed and 326(14\%) strongly disagreed. Teachers recruitment is conducted when principal make request in areas of need, indicated that 419(17\%) strongly agreed, 630(26\%) agreed, 1059(44\%) disagreed and 292(13\%) strongly disagreed. Recruitment of teachers are always kept in view after request from the principal for several years showed that 323(13\%) strongly agreed, 501(29\%) agreed, 1147(48\%) disagreed and 29(18\%) strongly disagreed to the item. Also, recruitment is not necessarily based on merit but equal representation from all the local Government Area showed that 401(17\%) strongly agreed, 425(52\%) agreed, 1265(52\%) disagreed and $309(13 \%)$ strongly disagreed to the item. In conclusion, it is evident that recruitment of teachers are not done through adequate publicity and consultant are not effectively used in the recruitment processes. Respondents are also of the view that principals' request in the area of needs in terms of the human resources is not adequately addressed. 


\subsection{Research question 2: What training programmes for staff will minimize indiscipline in public secondary} schools in Rivers State?

Table 2: Frequency and percentage representation of training programmes for staff.

\begin{tabular}{|c|l|c|c|c|c|c|c|c|c|}
\hline S/N & \multicolumn{1}{|c|}{} & \multicolumn{1}{|c|}{ SA } & $\%$ & A & $\%$ & D & $\%$ & SD & $\%$ \\
\hline 6 & $\begin{array}{l}\text { Workshop are regularly organize for staff } \\
\text { in the school }\end{array}$ & 216 & 9 & 523 & 22 & 1205 & 50 & 456 & 19 \\
\hline 7 & $\begin{array}{l}\text { Staff participate on computer-assisted } \\
\text { instruction, in which computers are used } \\
\text { to provide additional help to reduce } \\
\text { instructional time }\end{array}$ & 352 & 14 & 689 & 29 & 909 & 38 & 450 & 19 \\
\hline 8 & Staff participate regularly in conferences & 162 & 7 & 364 & 15 & 1303 & 54 & 571 & 24 \\
\hline 9 & Staff participate in in-house training & 294 & 12 & 430 & 18 & 1251 & 52 & 425 & 18 \\
\hline 10 & $\begin{array}{l}\text { Staff participation in in-service training } \\
\text { have lead to cooperation among staff }\end{array}$ & 538 & 22 & 1222 & 51 & 430 & 18 & 210 & 9 \\
\hline
\end{tabular}

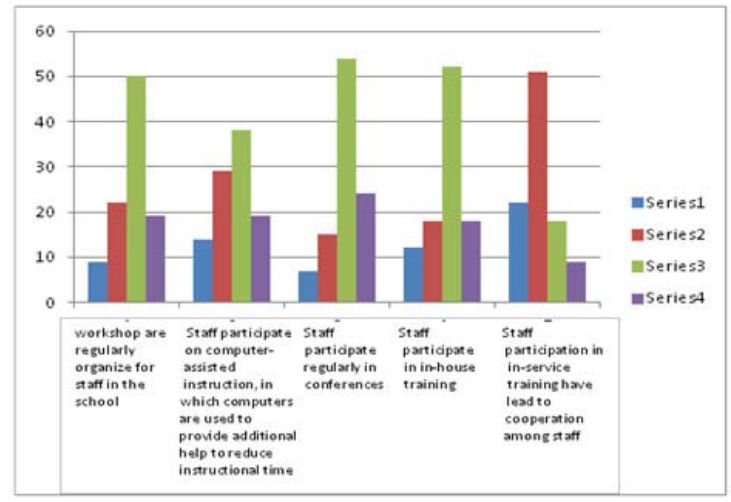

Figure 2: Frequency and percentage representation of training programmes for students and staff.

Table 2 and figure 2 showed the frequency and percentage representation of respondents (principals and teachers) on training programmes for staff. Out of 2400 respondents, 216(9\%) strongly agreed, 523(22\%) agreed, 1205 (50\%) disagreed and 456(19\%) strongly disagreed to workshop are regularly organize for staff in the school. 352 (14\%) strongly agreed, 689(29\%) agreed, 909(38\%) disagreed and 450(19\%) strongly disagreed that staff participate on computer-assisted instruction, in which computers are used to provide additional help to reduce instructional time. 162(7\%) strongly agreed, 346(15\%) agreed, 1303(54\%) disagreed and 571(24\%) strongly disagreed to staff participate regularly in conferences.294(12\%) strongly agreed, 430(18\%) agreed, 1251(52\%) disagreed and 425(18\%) strongly disagreed to staff participate in inhouse training. 538(22\%) strongly agreed, 1222(51\%) agreed, 430(18\%) disagreed and 210 (9\%) strongly disagreed to staff participation in in-service training have lead to cooperation among staff.

In conclusion, it is evident that training programmes such as conferences, workshop, Information and Communication Technology(ICT) and in-house training are not properly organized as at when due for staff.

\subsection{Research question 3: What compensation packages for staff will improve their personal needs?}

Table 3 Frequency and percentage representation of compensation packages for staff. 


\begin{tabular}{|c|l|c|c|c|c|c|c|c|c|}
\hline S/N & & \multicolumn{1}{|c|}{ SA } & $\%$ & A & $\%$ & D & $\%$ & SD & $\%$ \\
\hline 21 & Salaries are paid as at when due & 562 & 23 & 1361 & 57 & 365 & 15 & 109 & 5 \\
\hline 22 & Promotions are regular & 460 & 19 & 1261 & 53 & 450 & 19 & 229 & 9 \\
\hline 23 & Awards are given to individuals who perform & 225 & 9 & 652 & 27 & 1172 & 49 & 351 & 15 \\
\hline 24 & $\begin{array}{l}\text { Provision of incentive packages such as housing } \\
\text { loans, subsidies, allowances }\end{array}$ & 195 & 8 & 309 & 13 & 1355 & 56 & 541 & 23 \\
\hline 25 & $\begin{array}{l}\text { Organizing recognition fun such as parties for } \\
\text { staff, Christmas, Easter, Id-kabir etc. }\end{array}$ & 228 & 10 & 520 & 22 & 1358 & 57 & 293 & 12 \\
\hline
\end{tabular}

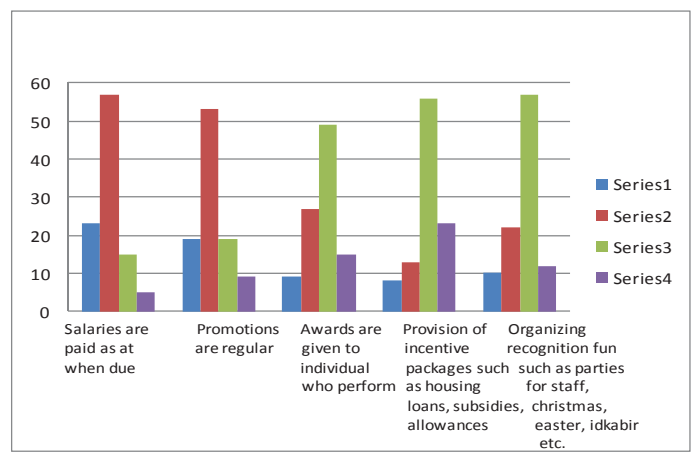

Figure 3: Frequency and percentage representation of compensation packages for staff.

Table 3 and figure 3 showed the frequency and percentage on compensation packages for staff will improve their personal need. Out of 2400 respondents, 562(23\%) strongly agreed, 1361(57\%) agreed, 365(15\%) disagreed and 109(5\%) strongly disagreed to salaries are paid as at when due. 460(19\%) strongly agreed, 1261(53\%) agreed, 450(19\%) disagreed and 229(9\%) strongly disagreed to promotions are regular. $225(9 \%)$ strongly agreed, 652(27\%) agreed, 1172(49\%) disagreed and 352(15\%) strongly disagreed to award are given to individuals who perform. 195(8\%) strongly agreed 309(13\%) agreed, 1355(56\%) disagreed and $541(23 \%)$ strongly disagreed to provision of incentive package. 228(10\%) strongly agreed, 520(22\%) agreed, $1358(57 \%)$ disagreed and 293(12\%) strongly disagreed to organizing recognition fun for staff.

In conclusion, there are compensation packages such as regular payment of salaries and promotion, however, provision of incentives such as housing, loans, subsidies, allowances are not adequately provided. Also, award are not often given for hard work.

\section{Discussion of Findings}

The analysis in table I showed that the method of recruiting of teachers in public secondary schools in Rivers State has not yielded desired results. Most respondents (71\%) were of the view that adequate publicity is not done in the recruitment processes of teachers. Even when principals make requests in areas were there are no teachers or teachers had been transferred, relevant authorities responsible for transfer or deployment of teachers have not acted faster so that those subjects would be taught. Rather such request are kept in view until when there is equal representation from all the local government areas in Rivers State at the expense of merit. However, Angelo and Brian (2008) are of the view that recruiting attracts job applicants from outside an organization. Notice of job vacancies should be placed through newspapers, employment agencies, executive recruiting firms, union hiring halls, college job-placement offices, technical training schools and word of mouth through professional associations. They also posited that the internet should be used, i.e online application and that most hand written applications simply disappear from the shelves cabinets. But 
with the online application, such is not possible. Also, they are of the view that selection processes should not be based on one criterion (Local Government Area), rather applicants should be tested on ability test, performance test, and other tests such as personality test.

On the training programmes for staff; workshops, Information and Communication Technology(ICT),and conferences are not regular in public secondary schools in Rivers State. This is evident in the result where $69 \%$ of the sample are of the view that workshop is irregular. $57 \%$ disagreed that staff participate on computer-assisted instruction, in which computers are used to provide additional help to reduce instructional time. Briggs \& Archibong as cited in Nosike, David, Nkasiobi and Opara(2011) reiterated that educational systems need to adopt new methods and formats that are suitable for present and future learners, that grasp and expand students low concentration span and provide them with interesting, up-to-date and engaging materials. These can be achieved through training. However, the Federal Ministry of Education is putting structures in place for the introduction of e-library in one hundred and four(104) unity colleges in the country, which have not been replicated in Rivers State Ministry of Education in the state-owned schools. 78\% say conference participation by teachers is not regular. The importance of conference programs for teachers cannot be overemphasis, as they expose teachers and principals to the ideas of speakers, who are professionals. Conferences also include discussions, which is a two-way communication allowing participants to either contribute, seek for clarification or critic on topics, which are relevant to teaching and learning. Also teachers do not participate fully in in-house trainings, where teachers are trained through coaching. It is the responsibility of experienced teachers who have been exposed to several training programmes to inculcate appropriate methodology in content delivery and classroom management. Effective in-house training will develop the strengths and potentials of teachers, which will help them overcome their weaknesses. It will also, save time and money, and will avoid costly mistakes by teachers in terms of teaching and learning. Angelo \&Brian(2008) stated that many employees of any organization need to be schooled in knowledge as the requirement of their field change. Thus, in the long run, it will benefit the schools, principals, teachers and students, such that quality delivery will be enhanced continually. However participation in in-service training is above 50\%. The establishment of the Universal Basic Education program and the need to have inclusive education has led to the increase in enrollment of pupils and students. There is the need for government to approve in-service training with pay for teachers either full time, part time or sandwich program (during holidays). There is the need for teachers and principals to continually update their knowledge in modern teaching and learning techniques and the use of modern instructional materials. Approval should not be selective to only Mathematics and English language. The Federal Ministry of Education held a workshop recently on Capacity-Building for teachers of Mathematics and English language, using Inclusive Education Approach on April 28 to May 11, 2013 for unity schools. At the workshop, teachers were trained on the need to have an inclusion classroom where regular, gifted, hearing impaired, visually impaired, mentally impaired, speech and language impaired and orthopedically impaired learners are to learn together with a teacher. However, these trainings have not been given to public schools owned by the Rivers State Government, and the adverse effect on the quality of education is enormous. Also Ogunloye (2012) was of the view that educators should have a common set of role responsibilities through training that cuts across the different expectations. These role-responsibilities include knowledge, advocacy, public enlightenment, collaboration, knowledge of the curriculum, knowledge of learners, instructional planning, instructional delivery, working with parents and community.

From the findings, salaries are paid to teachers as at when due with $80 \%$ affirming, and teachers are promoted on a regular basis (three years interval). However, awards are not given to individuals who excel in their areas of specialization or in the performance of other duties assigned to them for which $64 \%$ of the respondents hold this view. Incentive packages such as housing loans, subsidies and allowances are either partially provided or not provided. Also, recognition fun which are nonmonetary forms of compensation designed to enrich the lives of all the teachers in the secondary schools such as Christmas parties, Easter parties, end of session parties organized by welfare association, eid-elkabir etc, are not organized when 
necessary. To induce teachers to be more productive in terms of teaching and learning, school management should provide incentives such as bonus, hazard allowances, science allowance, housing scheme etc for teachers. Bureaucrat (2011) states that since the inception of the National Housing Fund, which was established by Decree No. 3 of 1992 now Act, no civil servant (teacher inclusive) has been granted loan to either build or buy his or her own house by the Federal Mortgage Bank of Nigeria (FMBN) which is legally authorized to administer the fund twenty (20) years after the scheme was introduced. The provision of shelter for teachers and other incentives is of great importance for the improvement of quality education. Some of these compensation packages serve as recreation. Parties are not organized for teachers by the management at the end of session, which is expected to bring together all teachers to unwind and relax. Little or no gift is given to the teachers by the school authorities at the end of the session to energize them to put in their best.

\section{Recommendations}

1. To enhance quality education, recruitment should be given adequate publicity so that qualified teachers will be aware, and recruitment agents should be used for the selection processes to reduce bottlenecks, and favouritism and should be based on merit.

2. Managers of school should regularly organize workshops, ICT training, conferences, and encourage teachers to improve their knowledge through the National Teachers Institute (NTI) and sandwich programmes.

3. Government should implement the conditions of service clause by clause, which clearly states the benefits of the civil servants (teachers).

\section{References}

Angelo, K. \& Brian K.W (2008) Management: A practical Introduction. New York: McGraw-Hill.

Armstrong, M. (2009). Armstrong's Handbook of Human

Resource Management Practice. India: Replika Press Pvt Ltd.

Association of Senior Civil Servant of Nigeria (2011), Strike Looms In The Public Service Over National Housing Fund. The Bureaucrat.1(3) 1.

Archibong,F.I \& Briggs, F.(2011).Impact of Innovation and Change on Contemporary Teaching and Learning as an Advancement from Myth to Reality. Journal of Educational and Social Research. 1(5),51-56.

Stoner, F.R.J, Freeman, E.R \& Gilbert, R.D (2007). Management. New Delhi: Prentice-Hall India Private Limited. 
